\title{
Regulations and Measure References of the Lottery Industry in China
}

\author{
Zehong Deng \\ School of Literature and Economics \\ Wuhan University of Science and Technology \\ Wuhan, China 430081
}

\author{
Peng Zhang \\ School of Literature and Economics \\ Wuhan University of Science and Technology \\ Wuhan, China 430081
}

\begin{abstract}
In China, after nearly 30 years development, the lottery industry has become a main form of raising funds for the purpose of developing social welfare. Through the analysis of China's lottery industry, there still exists the following three problems, the issuance operation lacks professional regulation institution, social supervision lacks legal and institutional safeguards, and the use of lottery welfare money lacks transparency and scientific measures. Learn from more comprehensive management experience of the lottery industry in Europe and the United States, this article will give some measures about the management of China's lottery industry and sustainable and healthy development.
\end{abstract}

\section{Keywords—lottery industry; regulations; references}

\section{INTRODUCTION}

Lottery industry in many countries was called 'soft finance', 'prospective tax', which plays an important part in financial financing and raising funds. [1] China's current lottery can date back to the mid-1980s, after nearly 30 years development, which has become matured. The administrative model of our lottery management system is ' $1+2+\mathrm{N}$ ': the state council has the right to approve the issue of lottery tickets; the ministry of finance is responsible for managing the lottery market, and making relevant laws and policies, which works with the ministry of civil affairs, the state sports general administration. They are responsible for making researches and making policies on how the earnings of lottery tickets are used. And supervise the use of lottery issuance, sales and lottery funds. Meanwhile, the ministry of civil affairs is mainly responsible for the issuance and sales of welfare lottery and management, distribution, and use of earnings. And the state sports general administration is mainly responsible for the sports lottery. The two are based on the laws and policies made by the ministry of finance. Clearly, the issuance of China's lottery, welfare lottery, and sports lottery both have their own system, and have their own channel.

\section{PROBLEMS IN CHINA'S CURRENT LOTTERY REGULATION}

In recent years, the domestic lottery was exposed many negative news, causing the public to question the credibility of the lottery business. China's current lottery issuance and

CLC Num.F723 Document Code: A Article ID management, especially the supervision of the lottery industry mainly exists the following problems.

\section{A. Supervision Lacks Legal and Institutional Safeguards}

At present, China has not yet had a sound and perfect laws and regulations to regulate the national lottery market. The issuance, management, and distribution of lottery lack relevant guidelines and support. Currently, some rules and some internal documents are playing a major role, but they are more broad and rough. Social public supervision has some difficulties in the specific implementation and operation.

The lottery competent authorities and issuers have the right to disclose and interpret information. The public as an important part of China's external supervision and management are difficult to access the effective information of China's lottery industry operating, which makes the external supervision lacks the possibility and operability.

Meanwhile, the media because of institutional constraints and its good cooperation relations with the lottery issuer, its public opinion supervision function is greatly restricted. More coverage of positive information, the issue of impartiality of lottery, the use of funds is rarely mentioned.

\section{B. Lottery Issuance Operation Lacks Full Time Supervision Agency}

China's current lottery industry administrative system: the state council approves the issued amount; the ministry of finance makes macro policies and supervises the issue. The specific issue sales of welfare lottery and sports lottery is respectively responsible by the jurisdiction of the lottery distribution center controlled by the ministry of civil affairs and the state sports general administration, which is a government functions overlap and relatively decentralized management system involved by many administrative departments in lottery administration, which is "binary lottery issuer, multiple lottery management model".

China's lottery issuer attached to the administrative department, because half of the public welfare funds of welfare lottery need to return to the ministry of civil affairs, which is the same with the half of the public welfare fund of sports lottery, which also need to return to the state sports general administration. And then the ministry of civil affairs 
and the state sports general administration will distribute and put into the social welfare and sports development. Driven by strong sectorial interests, the supervisory subject is difficult to ensure that is fair and strict, and it is difficult to carry out comprehensive supervision of its effect.

So, China's lottery industry will appear a department which possesses the right of management, distribution and supervision at the same time. One supervises oneself will lead to low management efficiency, weak market regulation and many other institutional management issues. The government should be decentralized, establish a professional agency to regulate the issuance and expenditure of lottery.

\section{The Use of Lottery Public Welfare Funds Lacks Transparency and Scientific Indicators}

The state council's Notice on Further Regulating Lottery Management regulates, the lowest money return rate is $50 \%$, the highest issuance fee rate is $15 \%$, lottery issuance management agencies get nearly $7 \%$ of the cost, the proportion of lottery fund should not be less than $35 \%$. But the information published by relevant departments is often more general, if the lottery chest is really used for public welfare is also difficult to verify. The use of $7 \%$ cost of the lottery issuance management agencies also lacks transparency.

$60 \%$ of the lottery will be used as a social security fund, the remaining $40 \%$ is mainly used for welfare and sports development. [2] In fact, the cost of public sports facilities mainly depends on financial allocations and social management. The use effectiveness of the lottery chest can only cover about $2 \%$, which lacks scientific standards.

Very fragmented and crude information disclosure, only a general ledger, not a detailed expenditure account, the public is still confused for where and how the lottery chest is used.

\section{EXPERIENCE OF EUROPEAN AND AMERICAN LOTTERY MANAGEMENT SYSTEM}

European and American lottery industry laws and regulations are perfect, which can effectively protect the source of government public funds, and crack private or corporate to issue illegal lottery. Besides, the lottery management system of Europe and the United States also shows the following different models and characteristics.

\section{A. Issuance and Supervision are Handled by the Local Authorities}

The issuance of lottery uses the model of government-led company collaboration. The regulation takes an independent regulation model which is a combination of centralization and decentralization. The representative of this model is the United States. [3] The lottery distribution rights in US scattered in the state government. The highest authority is the state government's lottery management committee, which is responsible for the formulation of policies and supervises the issue of lottery tickets. The direct issue and management of lottery are agented by the lottery company, which empowered the commission merchant to sell the lottery tickets. The consignment agent is required to apply to the state lottery company. After obtaining the corresponding license, they can obtain the market access qualification. The US lottery industry regulation reflects a kind of independent supervision which is a combination of centralization and decentralization. The US lottery regulatory does not have a national unified of centralized lottery management committee. This power is distributed to the state's lottery management committee, which is the full time institution of the lottery supervision. The United States, Canada, Germany, and Australia use this regulatory model.

\section{B. Distribution and Supervision was Assigned to the Central and Local according to the Different Nature of the Lottery}

The central government is responsible for the issuance and supervision of national lottery tickets. The local is responsible for the issuance and supervision of other lottery tickets. The representative is the UK. Be different from the US, the British national lottery is issued in the British parliament. Issued by parliament, according to the types, the lottery was issued and managed by the culture, publicity and sports and other different departments. The actual distribution work is handled by the dealer. The dealers selected by the national lottery committee through bidding was awarded lottery business license. The distribution rights of other lottery are in the local government. The regulation of the national lottery is focused on the UK national lottery commission. This institution is not affiliated with an executive branch of the government, but directly leaded by the secretary of state. The regulation rights of other lottery are in the local government, which is used to regulate if the dealers have a legitimate business.

\section{The Central Government Monopolizes the Regulation of one of more Departments}

The French lottery issuance regulation is a one-to-one model: a full time supervisor, a special sales company to issue lottery tickets-French national game group company, which is responsible for the issue of lottery issuance throughout the country. The French national game group is not completely "state-owned enterprises", which is owned by the French government who holds $72 \%$ of the shares. The remaining shares were owned by the company employees, retailers, and distributes. This is a mixed model of business controlled by the state. Europe also has some countries where lottery issuance regulation is a one-to-many model: a full time supervisor, many sales companies the issue of lottery tickets.

\section{National Banks and Local Government Co-managed}

Japan is the representative of this model. In this model, in order to unify the lottery industry management affairs, the central government designated a bank to manage the country's lottery distribution business. The lottery distribution plan will be submitted to the Council to get approval. The Japanese government has designated Japan's first bank to manage the country's lottery business. The 
lottery issuance was submitted to the local councils by local governments. After the deliberation was passed, they applied to the government for licensing to get the approval.

\section{SugGestions ON PERfECting CHINA's LOTTERY SUPERVISION}

After the analysis of the above, this article will give the following suggestions.

\section{A. Make separate specialized laws to regulate the development of the industry}

Although China's lottery industry has developed nearly 30 years, has not yet enacted a professional industry law, such as the "lottery law", which has become a tough problem for the sustainable development of the lottery industry in China. The developed countries have a good lottery operation and management, just because there is a necessary condition that they have a very perfect laws and regulations on the development of the lottery industry. China should make separate laws and regulations for the lottery industry.

\section{B. Establish a Relatively Independent Full Time Lottery Regulatory Agency}

China's ministry of finance, the ministry of civil affairs and the general administration of sports are the lottery industry regulators, but the ministry of civil affairs and the general administration of sports are also the issuing department. They also master the distribution and use of less than $35 \%$ of the total lottery welfare money and $7 \%$ of the lottery distribution management fee. [4] This kind of "selfregulation" lacks transparency, which is also difficult to realize. Learn from the experience of developed countries' lottery management system, we should set up relatively independent lottery supervision and management agencies, which should be directly affiliated with the State Department. It can be "China lottery supervision and management committee" and other similar names. And legislation shall define its duties and ensure the relative independence of its regulation. Meanwhile, construct a full time lottery supervision and management committee, form national lottery companies, unified release operation, establish a standardized market, integrated lottery issuance and operation system, and truly achieve separation and control each other.

\section{Improve the Use of Public Welfare Fund Management System}

First, the use of the welfare money should be highly transparent. Do not engage in one time delivery, assessment should meet the requirement and then give additional investment. The plan of using welfare money, from project to approval, all need to demonstrate by the committee. The using condition, content, and the following management of lottery welfare money should have definite regulations. And the using condition should have a detailed report. They should establish a transparent account, so that the public can participate in the supervision and control of the welfare fund.
Second, the use of the lottery fund can take the model of "centralized payment, state allocation". Bring in the public hearing system and evaluation system, curb corruption and promote the sustainable development of the lottery industry.

\section{REFERENCES}

[1] Wuyi Wang, Economics of Gambling [M], People's Publishing House, 2001.

[2] Ministry of Finance, Notice on Adjusting the Distribution Policy of Lottery Chest,[EB/OL],Ministry of Finance of the People's Republic of China, (2006-3-29) http://www.mof.gov.cn.

[3] John Wiley. The Gaming Industry: Introduction and Perspectives [M], 1996, 69-75.

[4] Yihang $\mathrm{Xu}$, The Loss the Lottery Funds[N], the Procuratorial Daily,2014-12-22. 